コンピューターによる顔面神経麻痺の評価

川本亮・磯野 道夫・村田 清高

斉藤 啓・宮下 仁良

\title{
Evaluation of Facial Nerve Paralysis Using a Computer
}

\author{
Makoto Kawamoto, Michio Isono, Kiyotaka Murata, \\ Kei Saito and Hiroaki Miyashita \\ (Kinki University)
}

House and Brackmann's grading system, Fisch's grading system and Yanagihara's 40-points method are widely used for the testing of the severity of facial paralysis. These methods are very convenient and simple, requiring no sophisticated instruments. Since these evaluations depend on the subjective judgment of the examiners, objectivity and reproducibility have always been the problem with these methods.

To address this problem, the movement of markers attached to a subject's face was measured with a video camera and a personal computer suitable for daily clinical practice. This method was useful for evaluating facial nerve paralysis quantitatively and objectively.

A new analysis system using a computer with an infrared camera allowed more detailed numerical evaluation of the velocity of facial movement. In the improvement process of paralysis, the differences between the right and the left side disappeared first in the movement distance and then in the velocity. When comparing the improvement course of paralysis in the orbicularis oculi area and the oris area, the orbicularis oculi area showed gradual uniform improvement corresponding to improvement in the 40points method, while the orbicularis oris area showed gradual initial improvement, followed by rapid improvement in many cases.

The infrared camera system shortens analysis time, but the cost is rather high. This method is useful for the evaluation of the reliability in scoring methods, objectively detailed evaluation of the mechanism of the movements of the facial expression muscles, and feedback of the analysis results for use in conventional scoring methods.

Key words : facial movements, objective evaluation method, facial nerve paralysis

\begin{abstract}
緒言
顔面神経麻痺患者における麻痺程度の判定は，世界的 には House-Brackmann 法1) の採用が普及しておう, 日本 では顔面神経研究会提唱の 10 項目 40 点法 ${ }^{2)}$ が広く用い られている. これらの評価法は, 特別な器具を必要とせ ず，誰にでも何処ででも行える簡便な検査であり，患者 に苦痛を与えないなどの利点から, 広く利用されている。
\end{abstract}

しかし反面これらの評価法は, 検者の主観に頼っている ために，検者の経験による差や，検者によって評価が異 なるなど，再現性等に疑問がもたれるようになった。 そ のため, 他覚的な顔面神経麻痺の評価法が要求された. 今まで色々な方法が報告されてきたが，広く臨床に応用 されるには至っていない，そこで著者らは，動画を簡便 に処理し得るコンピューターの機能に注目し, 取り込ん 
だ動画を分解して画像処理を加えることにより，顔面表 情運動の数量化に成功した ${ }^{3)}$. そして田中 ${ }^{4)}$ は，この方 法を用いて顔面の微細な運動を,顔面に貼り付けた 24 個 のマーカーによってできる三角形の面積について検討を 行うことで有意義な結果を報告した.

そこで，まずこの日常の臨床の場でも使用可能な安価 な家庭用ビデオカメラとコンピューターを用いた方法を 使用して, 顔面上のマーカーの移動距離を測った結果, 他覚的かつ定量的に優れた顔面神経麻痺の評価法である と考えられたのでこれを報告し，次にコンピューター解 析を駆使した新しい解析システムでさらに詳細な評価を 可能としたことで，今までに知り得なかった麻痺の改善 経過の特徵について解明したのでここに報告する。

\section{方 法}

1. 家庭用ビデオカメラを用いたコンピューターによ る解析

1）実験方法

（1）画像入力方法

測定に用いる顔面表情運動：40 点法や Fisch ${ }^{5)}$ の評価 法に含まれる強い閉眼運動，額のしわ寄せ運動，イーと 歯をみせる運動および口笛運動を用いた。

測定点：解剖学的な筋の配置を考えた上で再現性のあ る点を選び，顔面上に 24 カ所の測定点を設けた．測定点
に貼り付けるマーカーは, 直径 $6 \mathrm{~mm}$ の白色フェルト地 を利用した（図 1).

使用機器および測定方法：使用機器ならびに画像の取 り込み方法は磯野ら ${ }^{3)}$ ，田中 ${ }^{4)}$ が報告した方法に準じた。 顔面固定装置を作製し，これを用いて被験者の頭部を固 定し, 被験者に上記の 4 通りの顔面表情運動を行わせて, 顔とスケールを同時に家庭用ビデオカメラ（Sony 社製， CCD-TR55）で撮影する。このビデオ画像をコンピュー ター（アップル社製，Macintosh Quadra 840AV）に取り 込む.

（2）画像解析方法

取り込まれた画像は動画編集用ソフトウェア (Adobe 社製 Premiere）上で安静時から最大運動時まで 10 コマ の選別を行い不要な部分を削除した後，汎用画像解析用 ソフトウェア（NIH Image）で読み込む。ここで画像の 反転，2 值化の過程を経て顔面上のマーカーのみが抽出 される（図 2)。そして，画像上の各マーカーを座標軸上 の点に変換し, 安静時の鼻尖部の点を座標軸 $(0,0)$ と し，10 段階の顔面の動きに伴うマーカー各点の動き からその軌跡を計測した（Microsoft 社製 Excel）（図 3). 次に，これらの差の絶対值を求めることにより 移動距離を測定した。例えば，安静時のコマのあ る測定点が $\left(\mathrm{x}_{1}, \mathrm{y}_{1}\right)$ であったとすると次の画像であ る 2 コマ目は $\left(\mathrm{x}_{2}, \mathrm{y}_{2}\right)$ となっており，その移動距離は

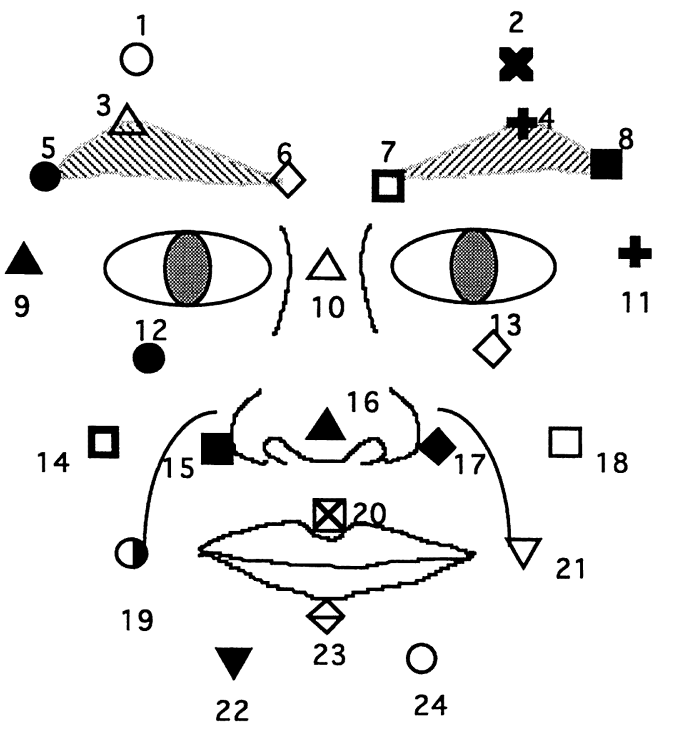

$\begin{array}{lll}\text { マーカー } & 1.2 & \text { 眉毛最上点の上方 } 1.5 \mathrm{~cm} \\ \text { マーカー } & 3.4 & \text { 眉毛上最上 } \\ \text { マーカー } & 5.8 & \text { 眉毛最外側 } \\ \text { マーカー } & 6.7 & \text { 眉毛最内側 } \\ \text { マーカー } & 9.11 & \text { 外眼角点の外側 } 1.5 \mathrm{~cm} \\ \text { マーカー } & 10 & \text { 左右内眼角結合線の中点 } \\ \text { マーカー } & 12.13 & \text { 眼窩点 } \\ \text { マーカー } & 14.18 & \text { 左右鼻翼結合線と外眼角点から垂直に } \\ & & \text { 下ろした直線の交点 } \\ \text { マーカー } & 15.17 & \text { 鼻翼点 } \\ \text { マーカー } & 16 & \text { 鼻尖点 } \\ \text { マーカー } & 19.21 & \text { 口唇交点の外側 } 1.0 \mathrm{~cm} \\ \text { マーカー } & 20 & \text { 上唇点 } \\ \text { マーカー } & 23 & \text { 下唇点 } \\ \text { マーカー } & 22.24 & \text { 口唇交点の外側 } 1.0 \mathrm{~cm} \text { とオトガイ点を } \\ & & \text { 結んだ直線の中点 }\end{array}$

図 1 測定点 


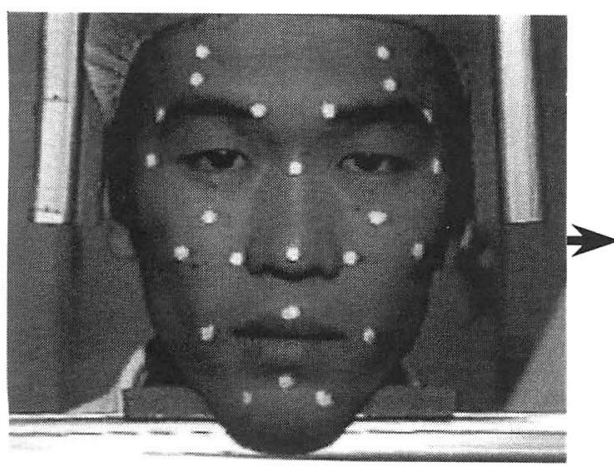

(A)

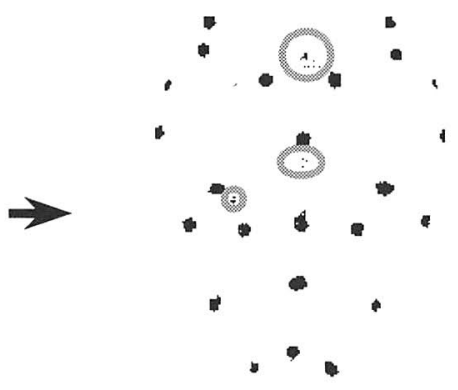

(D)

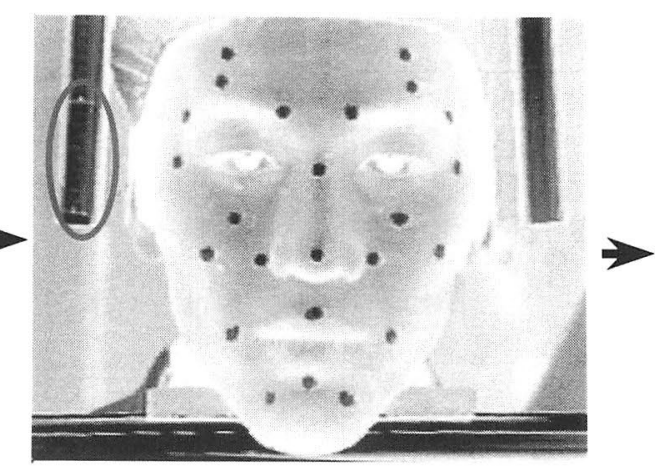

(B)

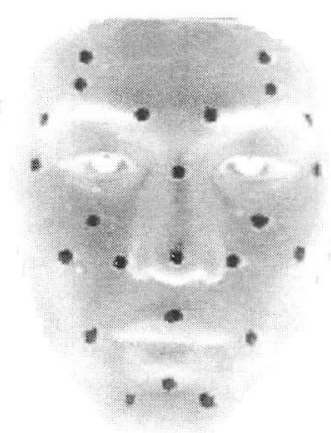

(C)

図 2 画像解析方法

ビデオ画像をコンピューターに取り込む（A）。顔面固定装置に取り付けたスケールを合わせ画像を反転させる（B）。顔面以外 の必要のない範囲を削除する (C). 2 值化処理を行い (D), マーカー以外の部位を消去する (E). コンピューターに各マーカー のラベリングを行わせる $(\mathrm{F})$. この時点で各マーカーの座標軸上の位置の評価が可能となる.

$\sqrt{\left(\mathrm{x}_{2}-\mathrm{x}_{1}\right)^{2}+\left(\mathrm{y}_{2}-\mathrm{y}_{1}\right)^{2}}$ となる.このようにして 10 コマす ベての移動距離を求めてその和を求めることで, 安静時 から最大運動時までの軌跡の距離が計測できる.

2) 実際の测定

(1) 対象

対象は顔面神経麻痺の既往のない健常成人 46 例 (男性 22 例, 女性 24 例） と, 顔面神経麻痺患者 12 例（ベル麻 痺 9 例，八ント症候群 3 例）である. なお, 顔面神経麻 痺患者はいずれも発症後 2 週以内に近畿大学医学部付属 病院耳鼻咽喉科外来を受診し, その経過を 3 週以上観察 できた症例である，被験者には，本研究の意義と検査上 の無害性を十分説明し，同意を得た。

(2) 検討項目

(1)正常者に対して

顔面上に貼り付けた24個のマーカーが顔面表情運動の 際に描く軌跡の距離を計算し，次の項目について検討し
た.

a）移動距離の検討

a-1）各顔面表情運動の際に顔面正中部の 4 個のマー カー（マーカー 10，16，20，23）のなかで移動距離が最 も小さいのはどのマーカーか（図 1).

a-2）顔面左右各 10 個のマーカー（マーカー 1，2，3， 4, 5, 6, 7, 8, 9, 11, 12, 13, 14, 15, 17, 18, 19, 21, 22，24）のなかで各顔面表情運動において最も移動距離 が大きなマーカーはどれか（図 1).

b）再現性の検討

b-1）努力の違いによる検討：男女 20 例の被験者におい て同じ動作を連続して 5 回行わせ，被験者の顔への力の 入れ具合の変化を検討し，その差を検討した.

b-2）検査日の違いによる検討：同一被験者において少 なくとも 1 日以上間隔をあけて, 検查日の違いによる差 を検討した。 

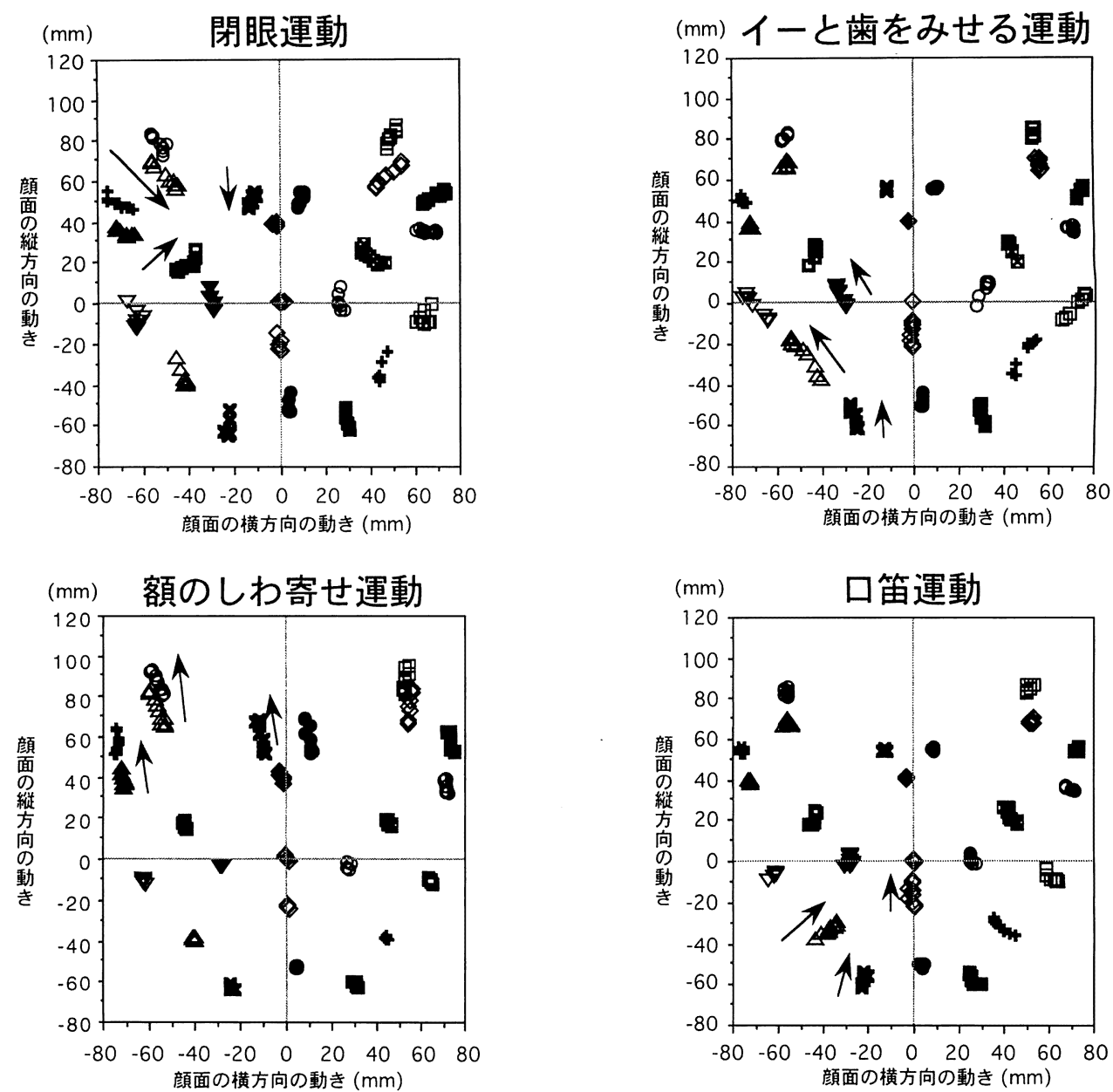

図 3 健常人における 24 個のマーカーの動き

(2)顔面神経麻痺患者に対して

顔面左右各 10 個のマーカー［上記 2)（2）(1)a-2)］を 検討の対象とし, 各顔面表情運動時における正常側の マーカーの移動距離の総和と麻痺側のマーカーの移動距 離の総和の比（ $\Sigma$ 麻痺側/正常側）を求めた。本研究では この比を顔面神経麻痺のデジタルスコア（以下，デジタ ルスコアと略す)と呼び, これを用いて以下の検討を行っ た.

a）顔面神経麻痺改善過程の評価

b） 40 点法との比較

40 点法については, 各検査日におけるスコアの点数を 40 で割って，デジタルスコアと同様に比で表現した.

2. 赤外線カメラを用いたコンピューターによる解析

1）実験方法

（1）画像入力方法
使用機器: マーカー; 半球型 $4 \mathrm{~mm}$ 赤外線反射マーカー (Qualisys 社製)

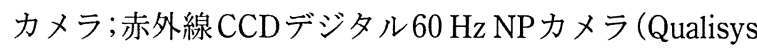
社製)

ビデオプロセッサ（Qualisys 社製）

画像取り込みソフトウェア；MacReflex 3D ソフトウェ ア (Qualisys 社製)

解析ソフトウェア ; Wingz ベース解析ソフトウェア (Investiment Intelligence 社製)

コンピューター ; Macintosh Quadra 840AV

測定方法 : 原理的には家庭用ビデオカメラを用いた方 法と変わらない，まず，顔面上に赤外線反射マーカーを 貼り付け，被験者に顔面表情運動を行わせる.これを今 までの家庭用ビデオカメラの代わりに赤外線 CCD デジ タル $60 \mathrm{~Hz} \mathrm{NP}$ カメラで撮影し, ビデオプロセッサで赤外 
線反射マーカーを抽出する. このデータはコンピュー ターに送られ, 動画解析ソフトウェアで赤外線反射マ一 カーの位置と移動に関する情報が数量化される。この データはWingz ベース解析ソフトウェア上でマーカーは 時間軸に沿った座標軸上のデータとして表現され，マー カーの移動距離や移動速度などが測定される ${ }^{6)}$ 。この方 法では, 測定開始から 9 分 6 秒 (毎秒 60 個の座標データ が得られるため計 32760 個）までの移動距離および移動 速度を解析することが可能となった。本研究での測定時 間は 10 秒間 (つまり 600 個の座標データが得られる) と し,この間に 5 回顔面表情運動を行わせて検討した.

(2) 画像解析方法

マーカーの移動距離および移動速度の測定方法の 1 例 を示した. (図 $4 \mathrm{~A} \sim \mathrm{D}$ ).

移動距離 $; \mathrm{A} ・ \mathrm{~B}$ のグラフは閉眼運動を 10 秒間に 5 回 行わせた時の眉毛最上点の $Y$ 座標の位置を示したもので ある. 縦軸に眉毛最上点の Y 座標の位置を示し横軸に時 間を示す。各々の波は閉眼から安静時に戻るまでの 1 回 の動きを示し，その振幅が Y 軸方向の移動距離である. 眉毛最上点の $\mathrm{X}$ 座標の位置についても各時間における データが得られるので $\left(\mathrm{x}_{1}, \mathrm{y}_{1}\right)$ から $\left(\mathrm{x}_{600}, \mathrm{y}_{600}\right)$ までの 600 個のデータが得られる.この 10 秒間の総移動距離の 左右比を求め評価を行った. 5 回の運動のなかで被験者

\section{マーカーの位置と時間の関係}

(閉眼運動)

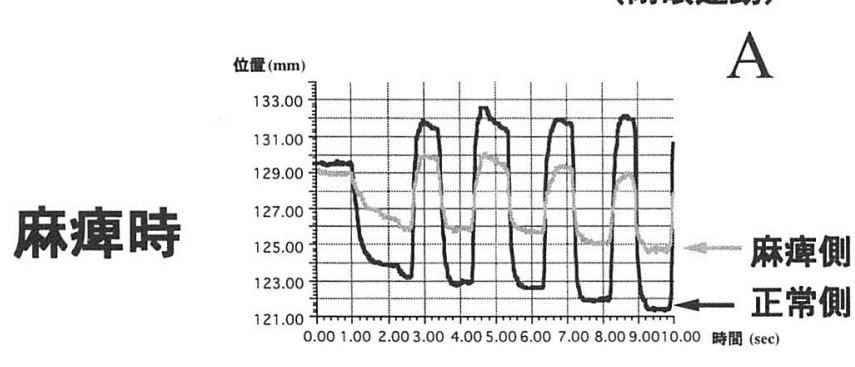

の努力の差によって多少振幅のばらつき，つまり移動距 離のばらつきが生じているのがわかる，しかし，正常側 の距離が大きい時は麻痺側の距離も大きいため, 左右比 で評価する場合は問題はない，また麻痺時（A）には，正 常側に比べ麻痺側の振幅が小さい，すなわち移動距離が 小さく, これに比べ麻痺改善時（B）には, ほとんど左 右の移動距離に差が認められないことがわかる.

移動速度; C・D のグラフは撮影開始から 10 秒間にお ける眉毛最上点の $\mathrm{Y}$ 軸方向の移動速度を示したもので, グラフの縦軸が眉毛最上点の $\mathrm{Y}$ 軸方向の移動速度であ り，横軸に時間を示している. 図のマイナスの部分が下 向きの速度つまり閉眼時の速度で，プラス部分が上向き の速度つまり閉眼から安静時に戻すときの速度を示して いる. マイナス部分の振幅の最大值が閉眼時の最大移動 速度でありこれの左右比を求め評価を行った. 移動距離 の場合と同じく被験者の努力の差によって多少振幅のば らつき，つまり最大移動速度のばらつきが生じているの がわかるが, 左右比で評価する場合は問題はない，また 麻痺時 (C) には, 正常側と比べ麻盘側では最大移動速 度が遅く, 麻痺改善時（D）には, ほとんど左右差を認 めなくなっていることがわかる。

2）実際の測定

（1）正常者に対して

\section{移動速度と時間の関係 \\ (闒眼運動)}

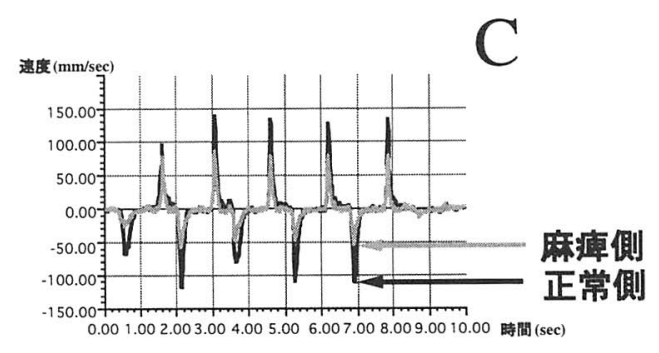

改善時

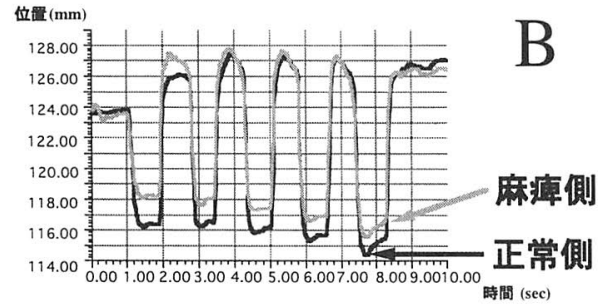

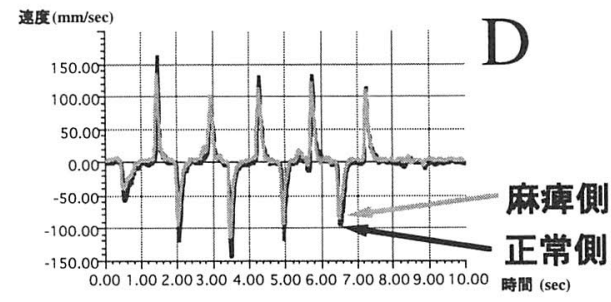




\section{(1)移動距離の左右比}

対象は顔面神経麻痺の既往のない健常成人 40 例 (男性 20 例，女性 20 例）である．顔面上の左右のマーカーの 移動距離を求めてその左右比を調べた。また左右の有意 差について $\mathrm{t}$ 検定（危険率 5\%）を用いて検討した。測 定するマーカーは，眼輪部ではマーカー 3，4（眉毛最上 点）とマーカー 6,7 (眉毛最内側点) を用い, 口輪部で はマーカー 19, 21（口唇交点の外側 $1.0 \mathrm{~cm}$ の点）とマー カー 22,24 (口唇交点の外側 $1.0 \mathrm{~cm}$ の点とオトガイ点 を結んだ直線の中点）を用いた。

(2)移動速度の左右比

対象は顔面神経麻舫の既往のない健常成人 63 例（男性 33 例，女性 30 例）について顔面上のマーカーの最大移 動速度を求めて左右比を調べた．測定するマーカーは眼 輪部ではマーカー 3,4 (眉毛最上点) を口輪部では, マー カー 22, 24（口唇交点の外側 $1.0 \mathrm{~cm}$ とオトガイ点を結 んだ直線の中点）を用いた。
（2）顔面神経麻痺患者に対して

対象はベル麻痺 8 例とハント症候群 4 例の計 12 例であ る. 検討した顔面表情運動は眼輪部は強い閉眼運動と額 のしわ寄せ運動を，口輪部はイーと歯をみせる運動を用 い, 各週ごとに各マーカーの移動距離の左右比と最大移 動速度の左右比を求めて次の $2 つ$ 項目について検討し た.

(1)顔面神経麻痺の改善経過について

(2)部位別な改善の検討（眼輪部と口輪部）

\section{実験結果}

1. 家庭用ビデオカメラを用いたコンピューターによ る解析

1）正常者の測定結果

(1) 移動距離

(1)各々の顔面表情運動における移動距離の小さな（動 きの小さい) マーカーについて
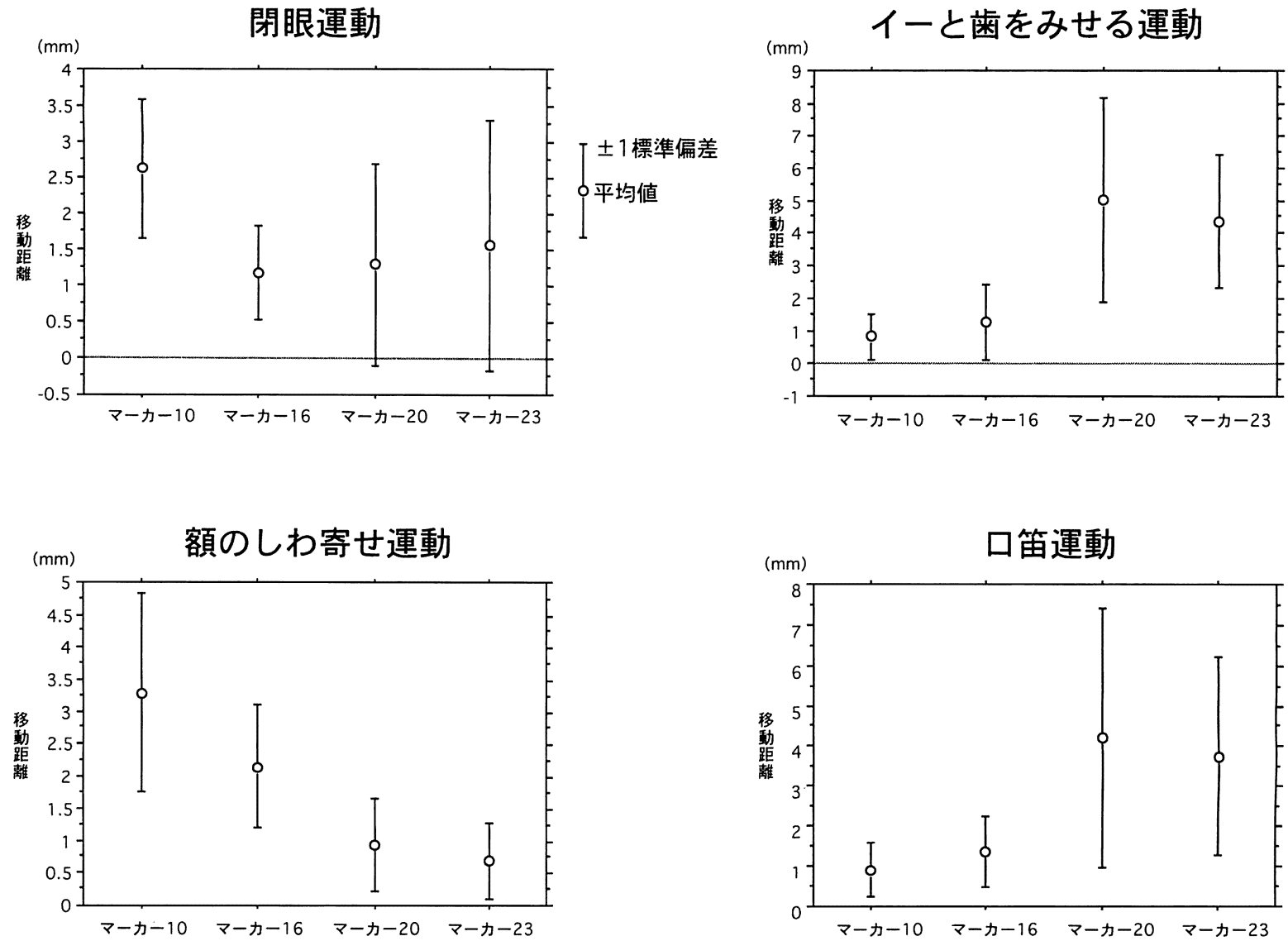

図 5 各顔面表情運動における顔面正中部の 4 個のマーカーの移動距離 

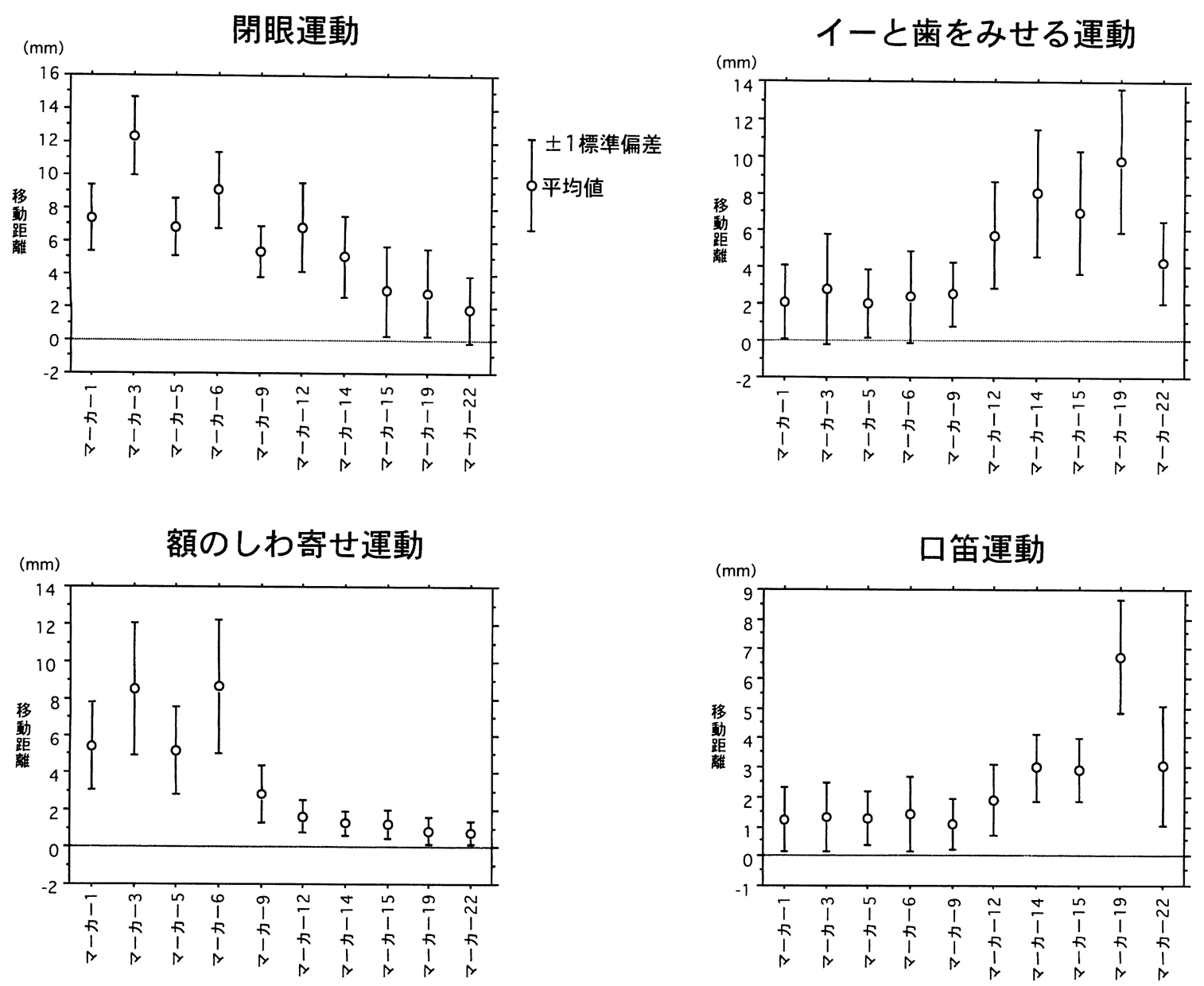

図 6 各顔面表情運動における右顔面の各マーカーの移動距離

健常成人46例の各顔面表情運動における顔面正中部の 4 個のマーカーの移動距離を検討した．移動距離が最も 小さいのは, 閉眼運動ではマーカー16 (鼻尖点) であり, 額のしわ寄せ運動ではマーカー 23 （下唇点）であった. イーと歯をみせる運動と口笛運動においてはマーカー10 （左右内眼角結合線の中点）であった（図 5).

(2)各々の顔面表情運動における移動距離の大きな（動 きの大きい) マーカーについて

健常成人 46 例の各顔面表情運動における右顔面の各 マーカーの移動距離を検討した. 閉眼運動と額のしわ寄 せ運動においては, マーカー3（眉毛最上点）とマーカー 6 (眉毛最内側点) の移動距離が大きかった. イーと歯を みせる運動と口笛運動では，マーカー19（口唇交点の外 側 $1.0 \mathrm{~cm}$ の点）の移動距離が大きかった（図 6).

(2) 再現性の検討結果

(1)努力の違いによる検討 : 被験者に閉眼運動を連続し
て 5 回行わせ, 各回の眉毛最上点の左右比（マーカー 3 / マーカー4）を検討した. 閉眼運動では 3 回以上の平均 を取れば，ほとんど差を認めなかった（図 7).

(2)検查日の違いによる検討：閉眼運動において移動距 離が大きかった眉毛最上点について検討した結果，検査 日によっては多少のバラツキがあるが，右側の動きの良 い日は左側の動きも良く，左右比ではその差はほとんど ないことがわかった．他の顔面表情運動においても同様 であった（図 8).

2) 顔面神経麻痺患者の検討結果

(1) 顔面神経麻痺改善過程の評価

麻痺患者の 1 週ごとの改善過程を検討した。ほぼ全例 においてデジタルスコアが 1 に近づくまでの麻痺の改善 傾向が数量的に評価できた（図 9).

（2） 40 点法との比較

麻痺患者のデジタルスコアと 40 点法の改善経過を比較 


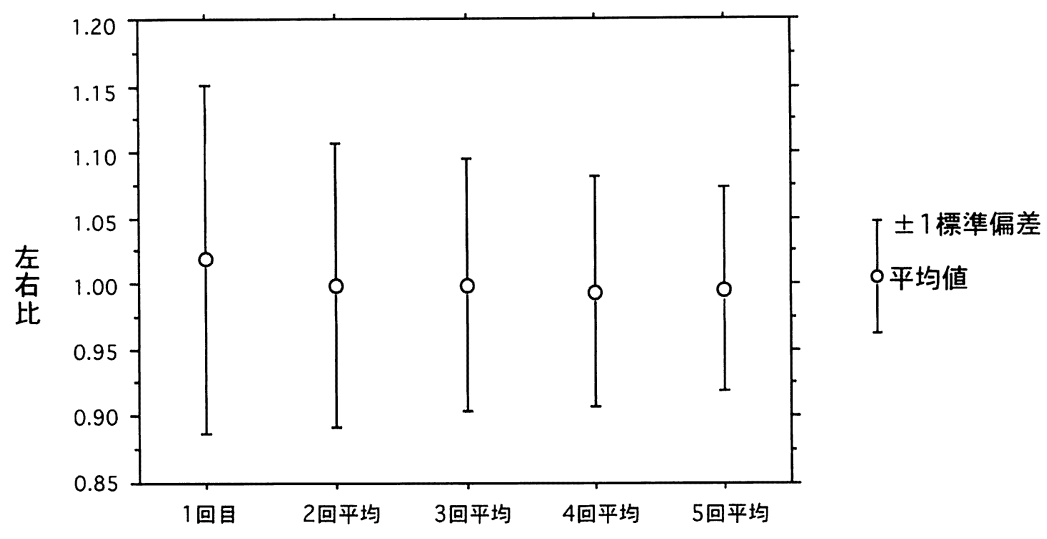

図 7 努力の違いによる再現性の検討（閉眼運動）

横軸に各回の平均值を(例えば 2 回平均とは, 1 回目の左右比と 2 回目の左右 比の合計を 2 で割った值である. ), 縦軸に 20 人の平均值と \pm 1 標準偏差を示 す. 3 回平均以上で標準偏差が 0.1 以下となった.

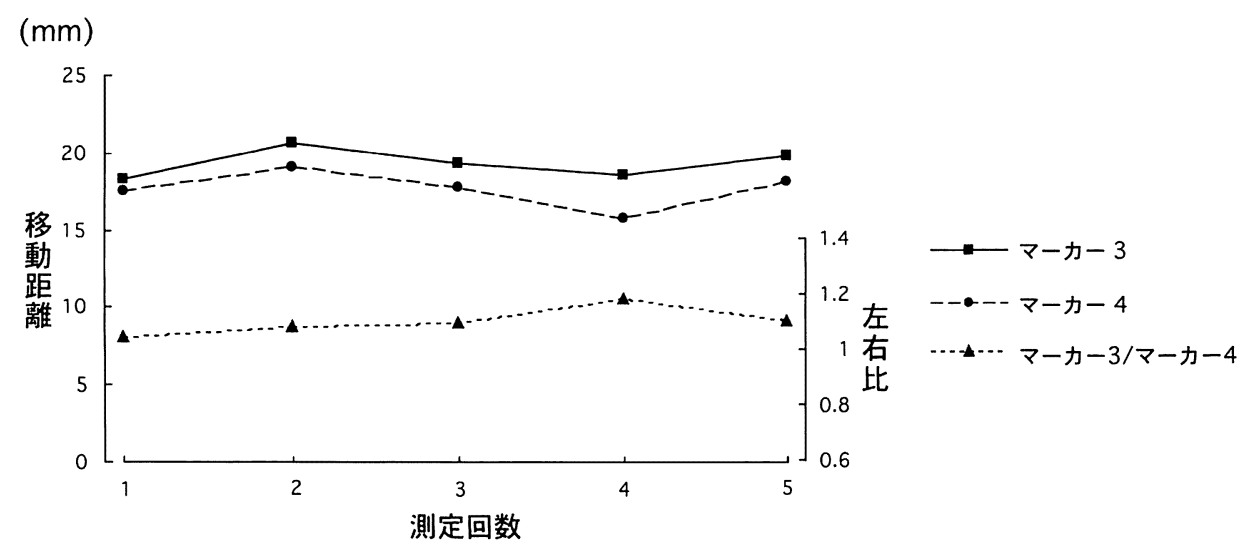

図 8 検查日の違いによる検討（眉毛最上点）

した (図 10). 12 例中 10 例において高い相関が得られた $(\mathrm{r}=0.91 \sim 1.00)$.

2. 赤外線カメラを用いたコンピューターによる解析

1）正常者の測定結果

（1）移動距離

各顔面表情運動における移動距離の左右比を図11に示 す.

閉眼運動において, マーカー 3 と 4 の左右比は $0.91 \pm$ $0.07(\mathrm{r}=0.97)$ ，マーカー6と 7 は $0.93 \pm 0.06 （ \mathrm{r}=$ 0.98 ), さらに眼輪部全体（マーカー $3+6$ とマーカー 4 +7 の比）でもその左右比は $0.95 \pm 0.05(\mathrm{r}=0.99)$ で，有意な差を認めなかった。

額のしわ寄せ運動においてはマーカー 3 と 4 の左右比 は $0.93 \pm 0.04(\mathrm{r}=0.97)$. マーカー 6 と 7 の左右比は
$0.94 \pm 0.05(\mathrm{r}=0.98)$, さらに眼輪部全体としての左 右比でも $0.95 \pm 0.03(\mathrm{r}=0.99)$ で, 左右に有意な差 を認めなかった。

イーと歯をみせる運動においてはマーカー 19 と 21 の 左右比は $0.92 \pm 0.06(\mathrm{r}=0.98)$, マーカー 22 と 24 の 左右比は $0.93 \pm 0.05(\mathrm{r}=0.97)$, さらに口輪部全体 (マーカー $19+22$ とマーカー $21+24$ の比) としての左 右比は $0.95 \pm 0.03(\mathrm{r}=0.99)$ で, 左右に有意な差を 認めなかった。

口笛運動においてはマーカー 19 と 21 の左右比は 0.92 $\pm 0.07(\mathrm{r}=0.96)$, マーカー 22 と 24 の左右比は 0.93 $\pm 0.05(\mathrm{r}=0.97)$, さらに口輪部全体でもその左右比 は $0.95 \pm 0.04(r=0.99)$ で, 左右に有意な差を認め なかった。 


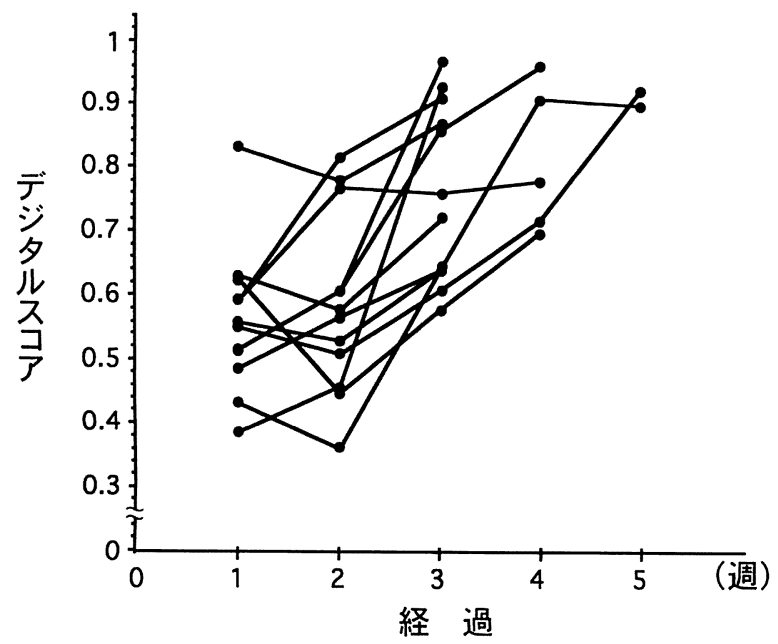

図 9 顔面神経麻痺改善過程

顔面神経麻盘患者 12 例の 1 週ごとの改善過程を示す。グ ラフの縦軸にデジタルスコア, 横軸に時間経過を示す.ほ ぼ全例において麻痺の経過に伴ってデジタルスコアが 1 に近づき，麻痻の改善傾向が数量的に評洒できた。 また 2 週目においてデジタルスコアの低下を認める症例が数例 認められた。

(2) 移動速度

各顔面表情運動における最大移動速度の左右比を図 12 に示す

閉眼運動においてはマーカー3 と 4 の左右比は $0.89 \pm$ $0.08 （ \mathrm{r}=0.96$ ）であった.

額のしわ寄せ運動においてはマーカー 3 と 4 の左右比 は $0.86 \pm 0.10(\mathrm{r}=0.94)$ であった.

イーと歯をみせる運動においてはマーカー 22 と 24 の 左右比は $0.88 \pm 0.10(\mathrm{r}=0.94)$ であった.

口笛運動においてはマーカー 22 と 24 の左右比は 0.88 $\pm 0.09 （ \mathrm{r}=0.96 ）$ であった.

いずれの運動においても左右の強い相関があることが わかった（Spearman および Kendall の順位相関係数, p $<0.01)$.

2) 顔面神経麻痺患者の測定結果

（1）麻痺改善経過について

顔面神経麻痺患者における眼輪部の移動距離および最 大移動速度の改善経過を図 13 に示す. 麻痺の改善経過を 理解しやすくするため，40 点法も加えた（縦軸をスコア /40にして表した). 全症例において麻痺の改善とともに 移動距離および最大移動速度の左右比が 1 に近づく, つ まり左右差がなくなる傾向を示した. 12 症例中 case 1 ,
2, 5 〜 11 の 9 症例においては移動距離の左右差が最大 移動速度の左右差よりも先に改善する傾向を示し, case 3，4，12 の 3 症例は移動距離と最大移動速度がほぼ同時 に改善傾向を示した。

（2）部位別な改善の検討（眼輪部と口輪部）

移動距離の左右比を用いた全症例の麻痺の改善経過を 図 14 に示す. 眼輪部は，40 点スコアと対応して経過と ともに徐々に均等に改善する傾向が強いことがわかる. これに対して，口輪部は，麻痺の当初は緩慢な改善を示 し，改善し始めると急速に改善する傾向を示した。

移動速度の左右比を用いた全症例の麻痺の改善経過を 図 15 に示す. 移動距離の場合と同様に眼輪部は, 徐々に 均等に改善する傾向が強く, 口輪部は, 麻痺の当初は緩 慢な改善を示し，改善し始めると急速に改善する症例が 多かった。

\section{考 察}

1. 家庭用ビデオカメラを用いたコンピューターによる 解析

1）正常者について

顔面表情筋は非常に多くの筋線維から構成されてお り，それらが協調して働き表情を作っているため，個々 の筋の働きを探ることは困難である，しかし，顔面の表 情はこれらの筋線維に加え皮下組織そして皮膚が緊密に 共同し合うある一定の大きさの領域の動きによって形作 られている.したがって，この領域を代表する点を選び， それらの点の動きを捕らえれば，顔面表情運動のアウト ラインを掴むことが可能となる.これらの点は解剖学的 な筋の配置を考えた上で再現性のある点を選択する必要 がある。ここでは，上記の事実をふまえた上で顔面上に 24 所の測定点を採用した（図 1). この測定点は Isono

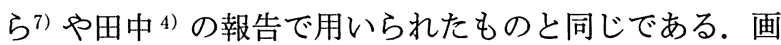
像の入力， 2 值化およびマーカーの位置情報の数值化の 過程はパーソナルコンピューターで動画が扱えるように なって以来，今では一般化した方法である。この手法を 顔面表情運動に応用したのは, 本邦では磯野ら ${ }^{3) 8)}$ が最初 である，本研究においてもこれらの報告と同様の方法を 用いた. これらの報告で解決されていなかったのは，顔 面表情運動の基準となる点をどこにするかということで あった．顔面表情運動を定量的に評価する際，表情運動 の大小あるいは，動きの違いに左右されない，全く動か ないか最も動きの小さい点を求め，その点を顔面表情運 

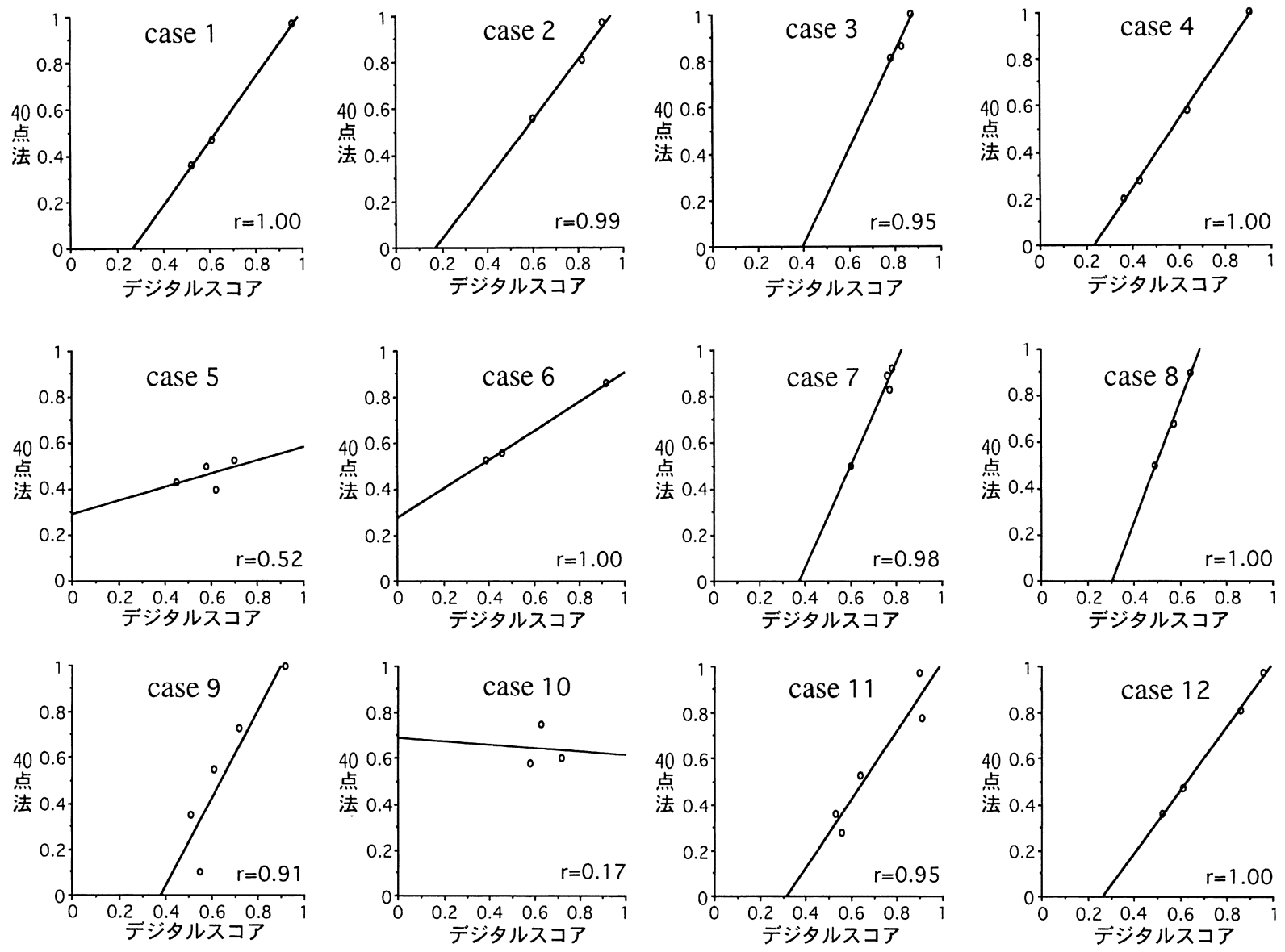

図 10 デジタルスコアと 40 点法の比較

40 点法と比較するために，縦軸に 40 点スコアを 40 で割った值を示し，横軸にデジタルスコアを示す．

動の基準（安静点, 補正点）とする必要性があった. し かし，それを検討した結果は，すべての顔面表情運動に おいて，動きが非常に小さい点はいくつかあるものの， 全く動かない点はなかった。 また，それらは各々の顔面 表情運動でそれぞれ異なっていた，各々の顔面表情運動 のなかで最も動きの小さいのは, 閉眼運動ではマーカー 16 (鼻尖点)，額のしわ寄せ運動ではマーカー23（下唇 点），イーと歯をみせる運動と口笛運動においてはマー カー 10 (左右内眼角結合線の中点) であった. これらの なかで, どの点を顔面表情運動の基準（安静点, 補正点） とするのがよいか考えてみると，閉眼運動においては鼻 尖点, また, 額のしわ寄せ運動では下唇点の動きが最も 小さく，これらの点で補正すれば良いと考えられたが, 病的共同運動が出現すると，眼輪部の運動の際には口唇 も動いてしまうために下唇点を補正に用いるのは好まし くない. 結局, 閉眼運動, 額のしわ寄せ運動ともに鼻尖
点が望ましいと考えられた。一方，口輪部の運動におい ては病的共同運動にて眼瞼部は動くが鼻根部は動かない ために動きの一番小さかった左右内眼角結合線の中点が 望ましいと思われた. よって本研究のすべての検討にお いて眼輪部の運動においては鼻尖点を，口輪部の運動に おいては左右内眼角結合線の中点を用いて補正を行うこ とにした．各々の顔面表情運動において全く動かない部 位がなかったという事実に関しては, 正常 42 例の顔面表 情運動を三次元的に検討し全く動かない顔面部位は存在 せず, 眼の動きについては口唇下部 $3 \mathrm{~cm}$ の部, 口の動き については左右内眼角結合点であったという Coulson ら9) の報告がある. この報告と本研究での結果（特に閉眼運 動時の結果）には相違点がある。この理由は，著者らの 検討が二次元的であることに起因し，微細な部分で異な るのは無理もないからである.いずれにせよこの報告は 顔面表情運動において全く動かない顔面部位はなく，し 

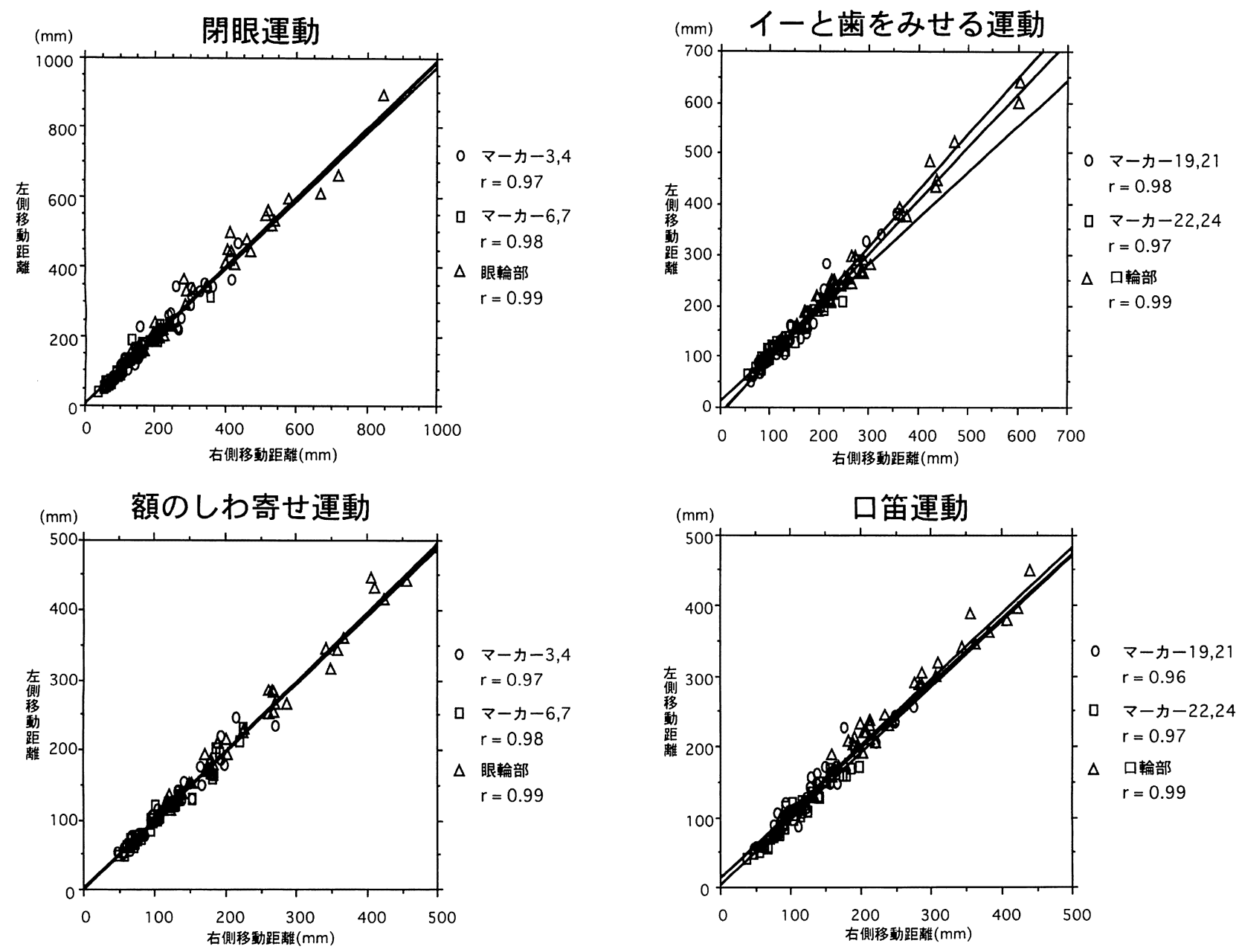

図 11 各表情運動における左右の移動距離の比較

グラフ縦軸に 10 秒間における左側マーカーの総移動距離を横軸に右側マーカーの総移動距離を示す.すべての表情運動におい て左右に強い相関関係を認める.

かも顔面表情運動ごとに基準点を設ける必要性があるこ とを示唆するものであった. 各顔面表情運動においてよ く動くマーカーは, 閉眼運動・額のしわ寄せ運動のよう な眼輪部の運動では眉毛最上点と眉毛最内側点, イーと 歯をみせる運動・口笛運動のような口輪部の運動ではい ずれも口唇交点の外側 $1.0 \mathrm{~cm}$ の点であった. 顔面表情運 動を評価する際には，これらの部位が重要な鍵をにぎる と考えられる.つまり，これらのマーカーが顔面表情運 動のダイナミックな動きを解析する際, 非常に重要な役 割を果たす部位を代表する点であり，これらの点を用い て顔面の動きを表現することにより，顔面表情運動のア ウトラインを把握することが可能となる．ちなみにこれ らの点が代表する領域は，たとえコンピューターによる
解析が簡単には行えない実地臨床の場での肉眼による評 点法の際にも，顔面表情運動を把握する上で非常に重要 な領域であることはいらまでもない.

これまで再現性については検者間の評価のばらつきに ついての報告10111) はあった。しかし，正常の顔面表情運 動について被験者の努力の差による差異や検査日の違い による差異などの報告はなかったので，本研究ではこの 再現性にかかわる問題の解明に，最大の注意を払った. 正常者に関して，1 回だけ検者の主観が入らない詳細な 検討ができたとしても，別の日に検査をして同じ結果が 得られないのであればその検査法の意義は大きく薄れ る.そこで検査日によっては顔のむくみなどにより「顔 の動きの悪い日が出てくるのではないか?」また「マー 

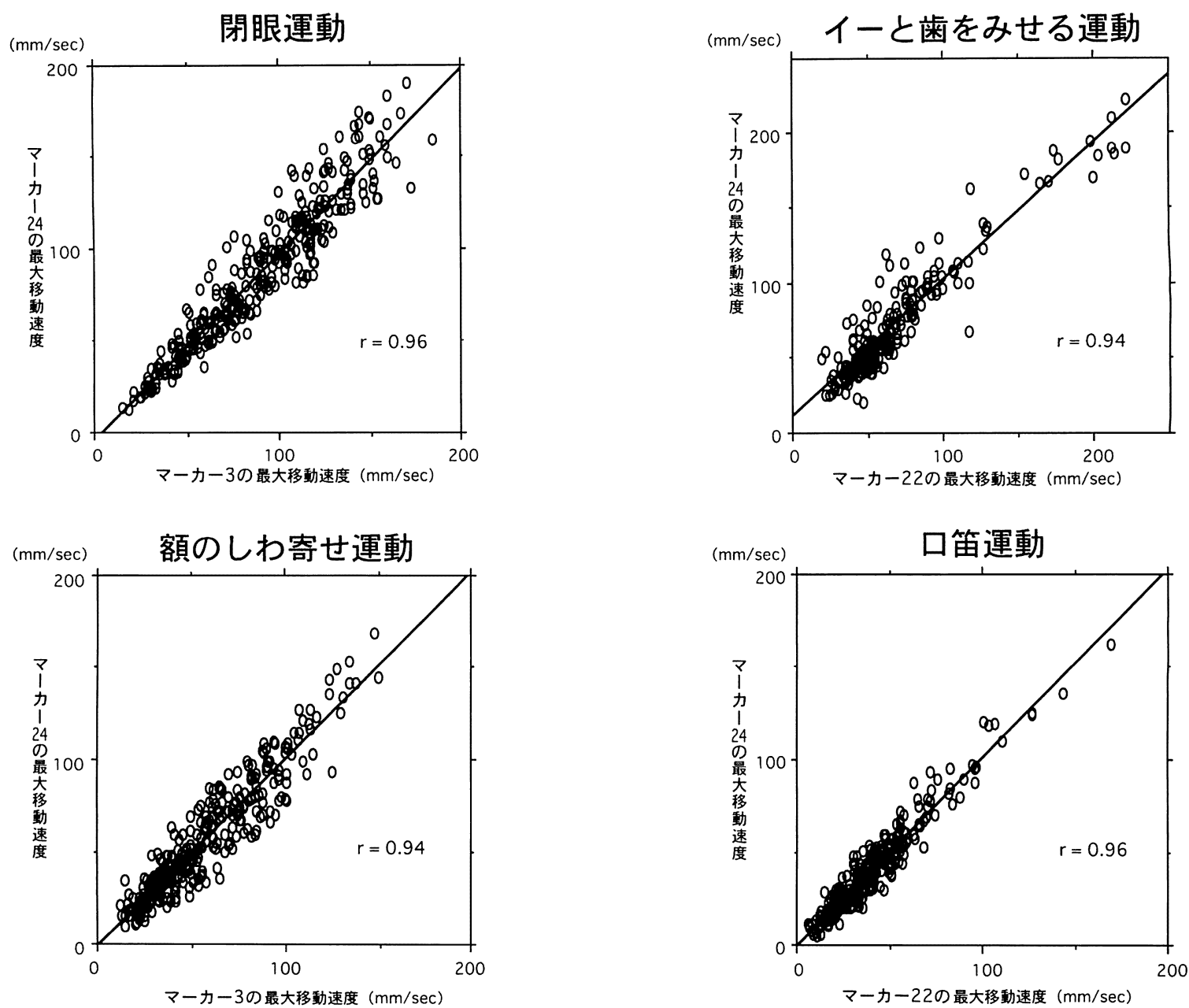

図 12 各表情運動における左右の最大移動速度の比較

グラフ縦軸に左側マーカーの最大移動速度を横軸に右側マーカーの最大移動速度を示す.すべての表情運動におい て左右に強い相関関係を認める.

カーを付ける部位が変わるのではないか？」と考えここ れらについて検討を行った。その結果は，被験者に最大 限の努力で顔面表情運動を行わせると，多少はその動き にばらつきがあった，そこで，真の值に近づくにはでき るだけ少ない回数で，何回同じ運動をさせて平均を取れ ばよいのかを検討した。 その結果，3 回程度同じ運動を させて平均を取ればその再現性に関して問題がないこと がわかった．検查日によっては顔の動きが良い日と悪い 日があったが，左右比を考慮する限りにおいて再現性に 問題はないことが示唆された。

以上の正常者の検討により著者らの評価法において再 現性と客観性において問題がないことが示唆され，本法 が顔面表情運動の他覚的評価に適用できることがわかっ
た.

2）顔面神経麻盘患者について

麻痺患者に関しては，症例によりさまざまな経過を示 す麻痺の改善過程が，数量的かつ客観的に評価すること ができた.また検討した 12 症例のなかに，2 週目に本法 の結果においてスコアの低下を認める症例が数例認めら れた。 これは麻痺の発症初期においてみられる麻㾝の増 悪を示唆していると考えられ興味深い。この初期の麻痺 の増悪はスコア法ではなかなか表現されにくく，本法の ような客観的評価法でなければ表現できないことであ り，この事実は本研究の重要な成果であるといえる。 た，麻疾の改善経過について，本法と 40 点法を同時に行 い比較した。 40 点法は各運動に対して 4 点， 2 点，0 点 

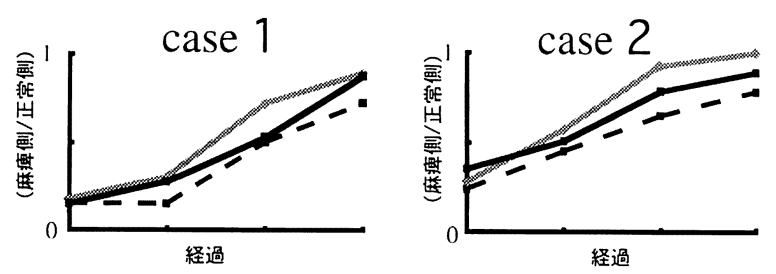

case 5
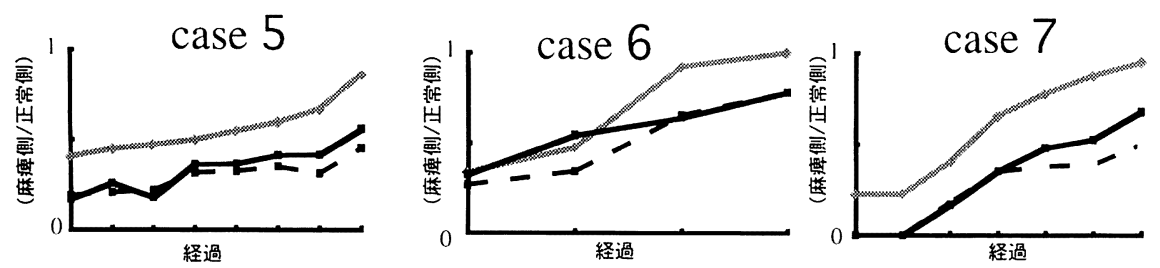

case 3
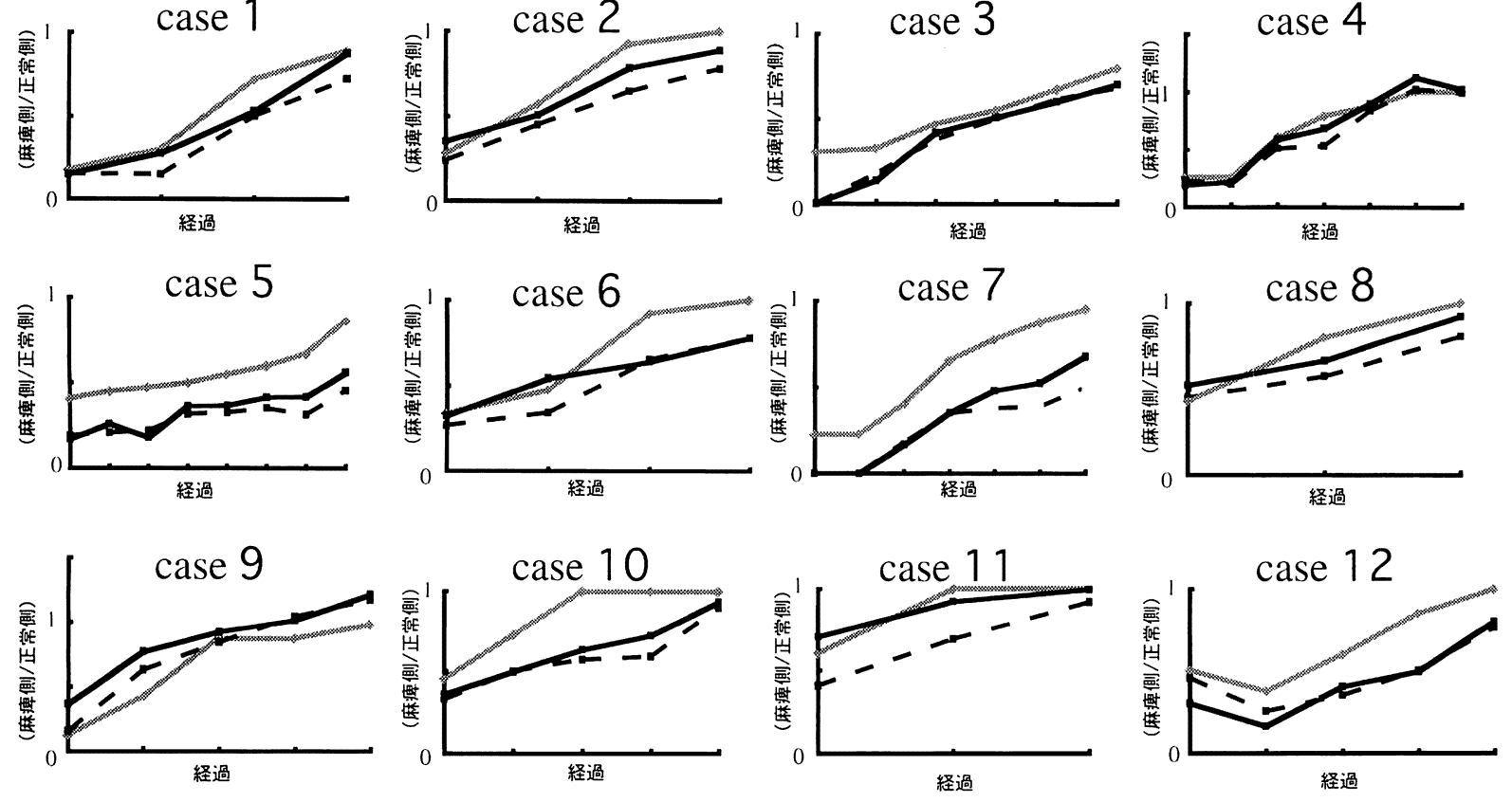

40点法
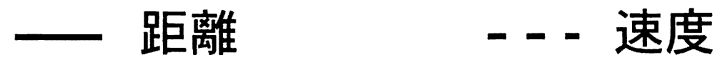

図 13 眼輪部の移動距離および移動速度の麻痺改善経過

眼輪部の值とは，額のしわ奇せ運動の左右比と閉眼運動の左右比の平均值である. グラフの縦軸に移動距離および最大 移動速度の左右比（麻㽻側/正常側）を，横軸に時間経過を示した. 40 点法については，縦軸を各週のスコア/40にし て表した。

の 3 段階スケールであり顔面の微妙な変化を判定するに はスケールが粗すぎる場合もあると考えられるが，耳鼻 咽喉科実地診療における標準的な評価法であり,この 40 点法との異同は重要な意味を持つ. その結果, 本法は 40 点法と高い相関関係にあり, 顔面神経麻瘏の評価が他覚 的かつ定量的に行え，顔面神経麻痺のデジタルスコアと して臨床応用が可能であることがわかった. なお，40点 法と相関関係が得られなかった 2 例（case 5 と case 10） は，麻痺の経過とともにデジタルスコアは改善している にもかかわらず40点法において麻瘨スコアが増減した症 例であった。

以上のことから家庭用ビデオカメラによる方法は安価 であり,顔面表情運動の評価を 40 点法よりも詳細に他覚 的かつ定量的に評価することが可能であることが示唆さ れた。

2. 赤外線カメラを用いたコンピューターによる解析

家庭用ビデオカメラによる方法は経済的であり, 評点 法と比べると顔面表情運動を他覚的かつ定量的に評価す ることが可能であったが，以下のような欠点があった.
画像取り込みコマ数/毎秒に限界があり, 画像処理の過程 が煩雑であったので, 顔面表情運動の解析が量的に限定 された.これらを改善するため, 赤外線 CCD カメラの 導入を行った。 その結果, 画像処理が簡略化され, かつ 毎秒 60 コマで画像の取り込みができるようになり, 時間 軸に沿った顔面表情運動の解析, つまりマーカーの移動 距離の解析に加え, 移動速度の解析も可能となった. 本 法の目的は赤外線 CCD カメラを用いたシステムを使用 し，これまでに不可能であったような詳細な表情運動を 解析することにある.

1）正常者について

一般に正常人の顔の左右差は約 1 割程度といわれてお り, 40 点法において 36 点以上で後遺障害の認めない症 例を完全治癒としている報告が多い. 田中 ${ }^{4)}$ の家庭用ビ デオカメラを用いたコンピューターによる解析法では, 左右差は $6 \%$ 以内であると報告している. 井口ら ${ }^{12)}$ はモ アレ・トポグラフィー法（モアレ法）で顔面表情運動時 の非対称性の分析を行った結果, 総合の平均では $3.2 \pm$ $0.5 \%$ の非対称率を示したとしている. 赤外線カメラを用 

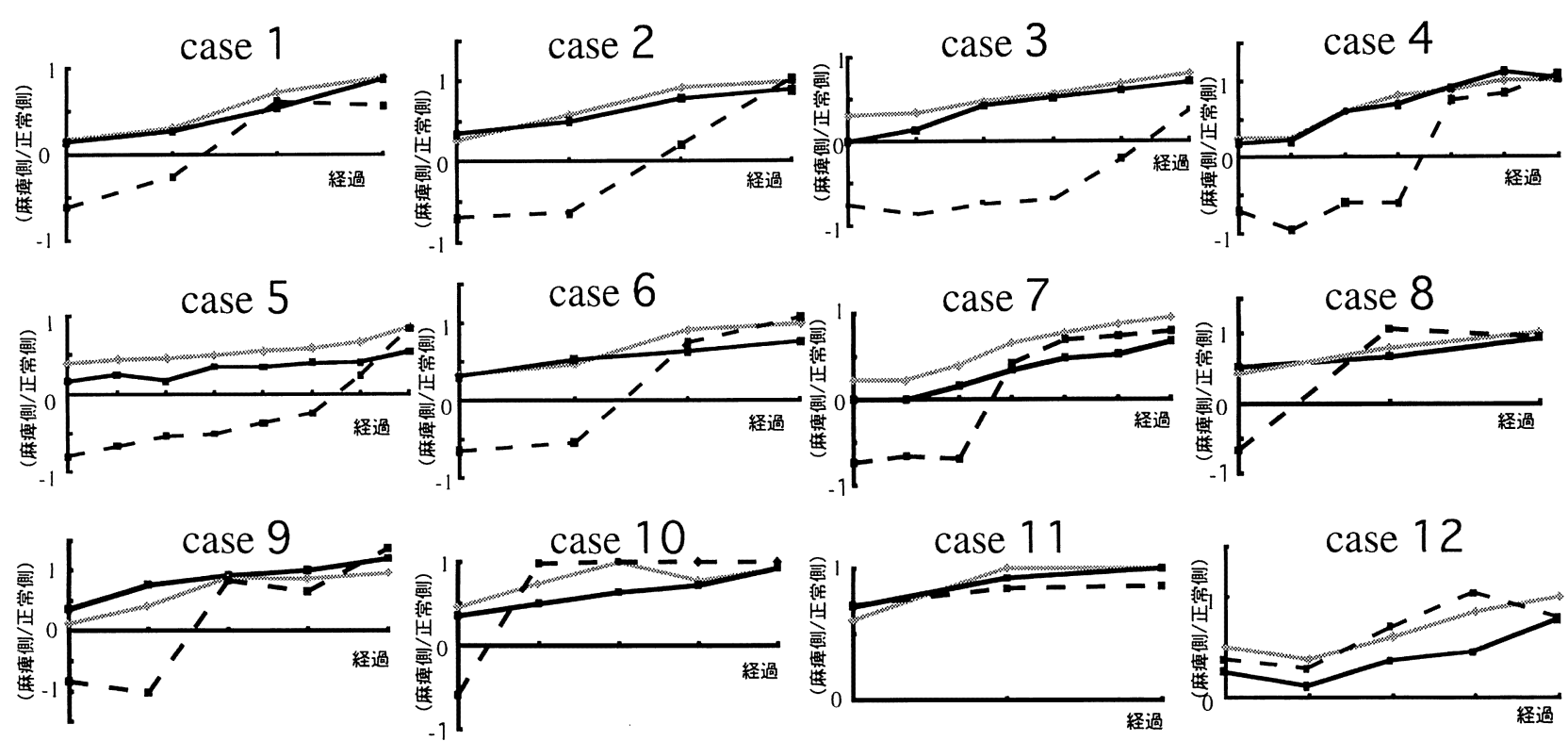

\section{- 40点法}

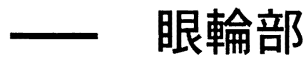

- - - 口輪部

図 14 部位別な改善の検討（移動距離）

グラフの縦軸に移動距離の左右比（麻痺側 / 正常側）を，横軸に時間経過を示した．麻痺の改善過程を理解しやすくするため 40 点法も加え, 縦軸に各週のスコア $/ 40$ の值として示した. 麻痺が強い時の口輪部における正常側へのひきつれはマイナスと して表される．麻痺の改善とともに眼輪部，口輪部の左右差がなくなる，つまり1に近づくことがわかる.

いた方法で移動距離の左右比を調べたところ閉眼運動, 額のしわ寄せ運動では眼輪部全体としての左右比はいず れも 0.95 であり, イーと歯をみせる運動，口笛運動にお

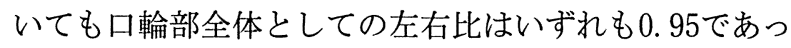
た.つまり $5 \%$ の非対称率を示した．顔面表情運動の客 観的評価法にはこれまでにいくつかの報告があるが，顔 面表情運動の移動速度についての報告例は著者らが渉猟 し得た限りに押いては認められなかった。 それは，顔面 表情運動そのものが瞬時に行われるために，経時的評価 が困難であったためであると推測される．著者らの方法 においてはこれが可能であったため移動速度についても 顔面表情運動の評価が可能であるかまず健常者において 検討した，検討に用いたマーカーの位置については, 眼 輪部においては左右の眉毛最内側点がかなり近い症例が 存在し正常側の影響を受けることが䯚念されたため，移 動距離が大きく正常側の影響を受けないマーカー 3,4 （眉毛最上点）を用いた。 口輪部の評価では眼輪部と違い 口輪筋という左右にまたがる筋が存在するために, 麻痺 患者に抢いては麻痺が強い時には麻痺側が正常側に引き
寄せられるという問題が生じる．実際にイーと歯をみせ る運動においては，マーカー19，21（口唇交点の外側 $1.0 \mathrm{~cm} ）$ が移動距離の大きなマーカーであったが，この 位置の主な動きはY 軸方向であったため麻痺側は正常側 と同一ベクトル方向に動き，その結果，麻盘が強い時に おいても正常側の影響を受け大きな移動速度になる。し たがって麻痺患者において移動速度の検討を行うために はこの正常側への引きつれを評価する必要がある、口輪 部の評価においては X 軸方向の動きが大きいマーカー 22, 24 を用いた。健常者における上記マーカーの最大移 動速度の測定の結果, いずれの顔面表情運動においても 顔面の左右の相関係数は 0.94 以上と非常に高い相関関係 を示し, 移動速度においても数量的な評価が可能であり, 麻痺の評価法の一手法として有用であると考えられたの で, 次に顔面神経麻舫患者において検討することにした。

2）顔面神経麻痺患者について

麻痺改善経過については, 移動距離, 移動速度の順に 左右差がなくなる傾向を示した。つまり麻盘の改善は, まず最大運動時の表情の差がなくなり，次に最大運動ま 

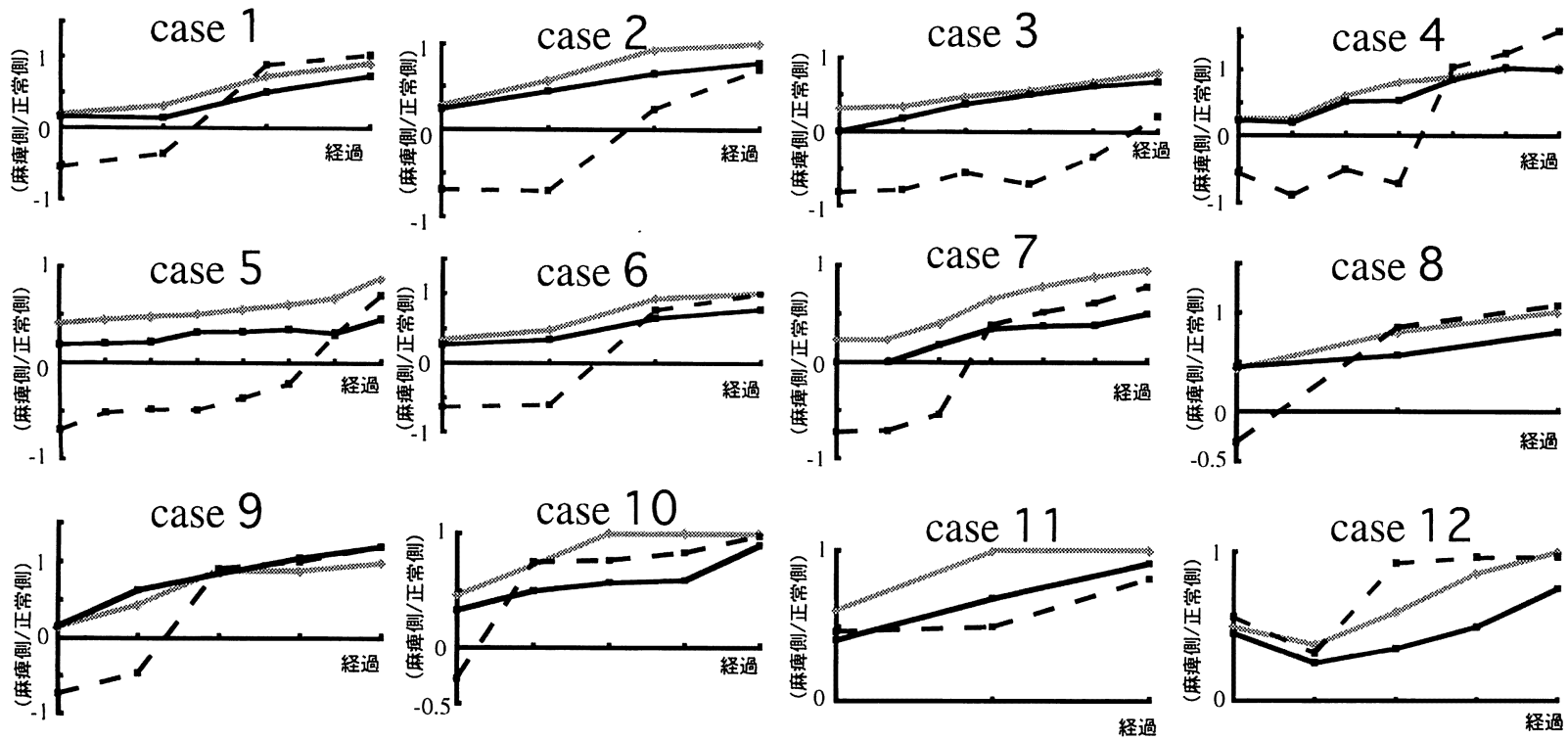

\section{0点法}

眼輪部

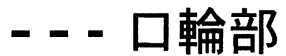

図 15 部位別な改善の検討（移動速度）

グラフの縦軸に移動速度の左右比を横軸に時間経過を示し，40 点法については，縦軸を各週のスコア $/ 40$ にて表した. 移動距離の場合と同様に，眼輪部の方が口輪部に比し先に改善傾向を示す症例が多かった.

での速度が改善する傾向を示した. 外来診療においては, 40 点法で評点する際に 40 点満点を付けているにもかか わらず，検者が肉眼的に最大運動時までの速度に差を認 めることや，患者が麻痺側の力が入りにくい等の違和感 を訴えることを経験したことがある．今回の結果で，40 点スコアが 40 点満点になっているにもかかわらず, まだ 移動速度は完全には改善していない症例が多かった。つ まり患者が麻痺側の違和感や力が入りにくいといった訴 えの背景には顔面表情運動における速度の改善の遅延が 関係あることが示唆された。したがって顔面神経麻痺の 改善を評価をする際には，顔面の左右の最大移動距離の 差がなくなった時点が麻痺の完全治瘉ではなく, 最大移 動速度の左右差がなくなった時点が麻痺の完全治癒とす るべきであると考えられた。このような結果は，顔面表 情運動速度の他覚的評価が可能となって初めて得られた ものであり，移動速度の評価は十分に意義があると考え られた。

顔面神経麻疾の部位別な検討について任 ${ }^{13)}$ は眼輪筋と 口輪筋について筋電図，誘発筋電図，強さ一時間曲線を 用いて検討を行った結果，口輪筋正中側の両側性支配の
ために眼輪筋の方が口輪筋よりも受傷性が高く，眼輪筋 の麻痺回復能が口輪筋のそれに比較して遅延すると報告 している. しかし実際の臨床経験においては眼輪部に続 いて口輪部が改善傾向を示すことが多いように思われ る．そこで著者らの方法を用いて検討した結果では，移 動距離と移動速度のどちらにおいても眼輪部は40点スコ アと対応して経過とともに徐々に均等に改善する傾向が 強く, 口輪部は麻舫の当初は緩慢な改善で，改善し始め ると急速に改善する症例が多かった。このことは，顔面 神経麻痺患者の改善経過において眼輪部が先に改善傾向 を示し，続いて口輪部の改善を認めるという著者らの臨 床経験に符合するものであった。任 ${ }^{13)}$ の報告と反対の結 果になった理由としては，筋電図の振幅が眼輪筋よりも 口輪筋で早期に記録されていても，著者らの方法は筋電 図等と異なり筋肉以外に顔面の皮膚や皮下組織などを含 めた顔面そのものの動きのすべてを評価しているために 正常側への引きつれが生じる結果，表情的には麻瘏が強 く感じられるためではないかと考えられる.

また，すべての症例で口唇下部のマーカーが麻痺側に 動くようになった時点の 40 点スコアは 20 点以上であり, 
その後は急速に麻痺が改善する傾向が強かった.これは, 正常側の影響がなければ本来なら麻痺側へわずかに動い ている場合でも，実際には正常側の力が強いために正常 側に引きつられるのでグラフ上では負となり，正常側の ひっぱりに対抗し麻痺側へと動くようになった時点では かなりの力が入っているため, スコアが 20 点以上に改善 していると考えられる。このように引きつれのなくなる 時期（負から正に逆転する点）で麻痺の予後をある程度 予測できることがわかった。

今回の報告のように顔面上の各部位における詳細な数 量的検討を可能としたことで，単純に眼輪部と口輪部の どちらが早く改善する傾向が強いかだけでなく，各部位 の麻痺の改善の特徴や麻痺改善の予測までも明らかとな り，興味深い結果であった。

3. 他覚的評価法について

顔面神経麻痺は耳鼻咽喉科医にとって決して珍しい病 気ではなく，麻痺を詳細に評価することの意義は大きい と思われる，顔面神経麻痺の程度を評価する方法として は, 検者の肉眼による評点法とコンピューター解析を用 いる他覚的評価法に大別される. 評点法は，われわれ人 間の微妙な表情の変化を認識する能力を用いることで誰 にでも何処ででも容易に行える結果，世界的に広く利用 さている評価法である．しかし人間の感覚に頼るところ が多いために，ある程度経験のある顔面神経の専門医が 評価した場合はその客観性は保たれるが，そうでない場 合は，どうしても検者の主観が入り客観的評価ではなく なってしまう危険性がある。したがって，検者の主観が 全く入らない他覚的評価法も必要となってくる. これま で, モアレ法1214) 19) やサブトラクション法20) 23), 顔

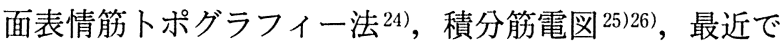
はオプティカルフローを用いた方法 ${ }^{27)}$ 考えられており さまざまな機器を用いた検者の主観が入らない方法が試 みられている。しかし, 評点法に取って代わるような簡 便な方法はいまだ開発されていないように思われる。 な ぜなら，これらの他覚的評価法はいずれも，何らかの機 材を用いなければならず，その過程は複雑になり評点法 のように簡単にはいかない，他覚的評価法がただ顔面神 経麻痺の経過を追うだけものであればその存在価值は低 く, 評点法で得られる結果に何らかの成果が上乗せされ なければその存在意義はないものといわなければならな い. したがって, 現在の他覚的評価法の研究の方向はふ たつに分けられると考朰れる.ひとつは，日常の臨床
に用いることが可能な安価で簡便に利用できるコン ピューターによる解析法の開発で，もうひとつは特殊な 機械やコンピューター解析を駆使することで評点法では 解析できなかった顔面表情運動の詳細な検討を行うとい う研究である，そこで著者らは，まず安価な家庭用のビ デオカメラとコンピューターを用いることでの他覚的評 価を可能とした．さらに多少高価になるが赤外線カメラ を用いて顔面表情運動および麻痺経過の詳細な検討を 行った。 その結果，評点法ではわからなかったが著者ら の方法で初めてわかったことがいくつかあった。例えば 正常者においては, 顔面表情運動の際によく動く点と動 きの少ない点があったり, 麻痺患者においては移動距離 に比べて移動速度の改善が遅れるなどの顔面神経麻痺の 改善経過の特徴があった。本法によれば，人間の目だけ では見落としがちな細かい部分的な動きをとらえ数值化 することができ，さまざまな有意義な検討結果が得られ た. ただ家庭用ビデオカメラの方法は安価ではあるが解 析に時間を要し, 赤外線カメラ法は短時間に評価が可能 であるが多少費用がかかるため何処の施設でも臨床の場 で用いるという訳にはいかない，したがって実地臨床の 場において評点法に取って変わるものではないが，評点 法の信頼性を検討したり，評点法ではわからなかったよ うな顔面表情運動のメカニズムを客観的に詳細に検討す ること,さらにはその結果を逆に評点法へフィードバッ クすることなどには貢献しうるものと考える.このよう に著者らの方法は評点法による評価を他覚的に検討する ことにより別の観点からサポートし，評点法で不足する 点を補足して行く立場にあると考えている.

今回の赤外線カメラ法を用いた麻痺患者の検討におい て，口笛運動は検討に加えなかった。それは口笛運動は 立体的な要素が強く, 麻痺時も麻痺改善時も同一ベクト ル方向に動き正常側の影響を受けるために二次元的な評 価では困難であったからである．著者らの赤外線カメラ 法では赤外線カメラを 2 台にすることで三次元の評価も 可能であり ${ }^{28)}$ ，さらに加速度の検討む容易でこれらにつ いては今後の研究課題としたい.

\section{結 語}

安価な家庭用ビデオカメラとコンピューターを用いる 方法と赤外線カメラを用いる新しいシステムを用いて顔 面表情運動の他覚的評価を行ったそその結果，以下の結 論を得た. 
1. 顔面表情運動を評価する際には眼輪部の運動につ いては眉毛最上点, 口輪部の運動においては口唇交点の 外側 $1.0 \mathrm{~cm}$ の点を注目すると容易であった.

2. 他覚的評価を行うには眼輪部の運動においては鼻 尖点, 口輪部の運動においては左右内眼角結合線の中点 を用いて補正する必要があった。

3. 再現性について検討した結果, 顔面表情運動の評価 を行うには数回の平均を取る必要があった。

4. 正常者で最大移動速度について検討を行った結果, すべての顔面表情運動において左右の最大移動速度は高 い相関関係を示し, 数量的な評価が可能であることが示 唆された.

5. 麻痺の改善に伴って, 移動距離, 移動速度の順に左 右差がなくなる傾向を示した.

6. 改善経過を部位別に検討したところ，眼輪部は 40 点スコアと対応して経過とともに徐々に均等に改善する 傾向が強く, 口輪部は麻痺の当初は緩慢な改善で, 改善 し始めると急速に改善する症例が多かった。

7. 著者らの方法ではさまざまな経過を示す麻痺の改 善過程を40点法よりも詳細に数量的かつ客観的に評価す ることが可能で, 顔面神経麻痺の評価に臨床応用が可能 であることがわかった。

\section{謝辞}

稿を終わるに臨み, 終始懇切なるご指導ご校閲を賜りました 村田清高教授に深甚なる謝意を捧げます. また, 本研究の完成 まで終始直接ご指導頂きました磯野道夫博士に深く感謝申し上 げます，本研究に際しご協力頂きました本教室医局員各位およ び被験者の方々にお礼申し上げます。

\section{参考文献}

1) House JW and Brackmann DE : Facial nerve grading system. Otolaryngol Head Neck Surg $93: 146 \sim 147,1985$.

2）柳原尚明, 西村宏子, 陌 啓芳, 他：顔面神経麻凂程度の 判定基準に関する研究. 日耳鼻 $80: 799 \sim 805,1977$.

3）磯野道夫, 村田清高, 箕山 学, 他 : 顔面表情運動の計量 診断の試み. Facial N Res Jpn 13:173〜 177, 1993.

4）田中久哉：顔面表情運動の定量的検討. 耳鼻臨床 補 $71: 1$ $\sim 20,1994$.

5) Fisch U : Surgery for Bell's palsy. Arch Otolaryngol $107: 1 \sim$ $11,1981$.

6）磯野道夫, 村田清高, 宮下仁良, 他 : 赤外線カメラを用い た顔面表情筋運動の検討. Facial N Res Jpn $17: 119 \sim 121$, 1997.
7) Isono $\mathrm{M}$, Murata $\mathrm{K}$, Tanaka $\mathrm{H}$, et al. : An objective evaluation method for facial mimic motion. Otolaryngol Head Neck Surg $114: 27 \sim 31,1996$.

8）磯野道夫, 村田清高, 田中久哉, 他 : コンピューター画像 処理を利用した顔面神経麻痺の他覚的評価法. 日耳鼻 97 : $393 \sim 400,1994$.

9) Coulson SE, Croxson GR and Gilleard WL : Three-dimensional quantification of "still" points during normal facial movement. Ann Otol Rhinol Lalyngol $108: 265 \sim 268,1999$.

10）佐藤靖夫, 大内利昭, 吉原重光, 他: 40 点法と HouseBrackmann 法の互換表一検者間のばらつきからみた検討 一. Facial N Res Jpn $14: 163 \sim 166,1994$.

11）佐藤靖夫, 大内利昭, 吉原重光, 他 : 顔面神経機能評価に おける評価基準ビデオ作成の試み. Facial N Res Jpn 15:101 $\sim 105,1995$.

12）井口郁雄, 川上晋一郎, 前田 学, 他：モアレ法による顔 面運動時の非対称性の分析. Facial N Res Jpn 10：165 168, 1990.

13）任 重：側頭骨内顔面神経麻盘における眼輪筋と口輪筋 の受傷性に関する瀶床的および実験的研究. 耳舅臨床 78 ： $249 \sim 268,1985$.

14）川上晋一郎, 井口郁雄, 前田 学, 他 : モアレ法による顔 面神経麻痺の程度評価法. Facial Nerv Res 10: 169 172, 1990.

15）前田 学, 井口郁雄, 川上晋一郎, 他 : モアレ縞パターン による顔面神経麻痺の評価. Facial Nerv Res 11:199～202, 1991.

16）井口郁雄，前田 学，川上晋一郎，他：モアレ法による乳 幼児顔面神経麻痺の評価. Facial Nerv Res 11：203〜 206, 1991.

17）井口郁雄, 結緣晃治, 前田 学, 他：顔面神経麻㽻程度評 価へのモアレ法の応用. Facial Nerv Res 12:85 90, 1992.

18）井口郁雄：モアレ法による顔面神経麻痺の程度評価法の開 発. 日耳鼻 $95: 715 \sim 725,1992$.

19）結縁晃治, 前田 学, 井口郁雄, 他：総合モアレ指数と 40 点評価法との比較. Facial Nerv Res $15: 91 \sim 94,1995$.

20）内藤 泰, 庄司和彦, 中村 一, 他：ビデオ画像のデジタ ル処理による顔面神経麻痺程度の判定. Facial N Res Jpn 9： $83 \sim 86,1989$.

21) Neely JG, Cheung JY, Wood M, et al. : Computerized quantitative dynamic analysis of facial motion in the paralyzed and synkinetic face. Am J Otol $13: 97 \sim$ 107, 1992.

22）高北晋一, 藤田修司, 内藤恵理, 他：画像解析による客観 的顔面神経麻痺程度判定一サブトラクション法について 一. 耳鼻臨床 $86: 61 \sim 66,1993$.

23) Scriba H, Stoeckli SJ, Veraguth D, et al. : Objective evaluation of normal facial function. Ann Otol Rhinol Laryngol 108:641 $644,1999$. 
24）小幡悦朗 : 表情筋トポグラフィーの開発と臨床応用. 耳鼻 臨床 $81: 815 \sim 832,1988$.

25）佐藤由宇, 浜田昌史, 中谷宏章, 他 : 顔面神経麻痺程度の 定量的評価法一積分筋電図と表情運動スコアの比較一. Facial N Res Jpn $15: 95 \sim$ 100， 1995.

26）中谷宏章, 浜田昌史, 竹田泰三, 他 : 積分筋電図による表 情運動の他覚的評価. Facial N Res Jpn $20: 8 \sim 10,2000$.

27）田村友洋, 國弘幸伸, 南谷晴之, 他 : オプティカルフロー を用いた顔面神経麻痺の客観的評価の試み. Facial N Res
Jpn $19: 64 \sim 66,1999$.

28）斉藤 啓, 磯野道夫, 川本 亮, 他 : 顔面表情運動の三次 元的解析. Facial N Res Jpn $20: 74 \sim 76,2000$.

原稿受付：平成14年 9 月 13 日

原稿採択：平成14年11月 5 日

別刷請求先 : 川本 亮

厂589-0014 大阪狭山市大野東377-2

近畿大学医学部耳鼻咽喉科学教室 